\title{
Paternalistic Leadership and Employee Responses in Javanese Culture
}

\author{
Dodi W. Irawanto* \\ Management Department, Faculty of Economics and Business, Brawijaya University, Malang, Indonesia \\ Phil L. Ramsey \\ School of Management, Massey University, Palmerstone North, New Zealand
}

\begin{abstract}
While much has been written about leadership research, little effort has been made to identify what constitutes effective leadership in an Indonesian cultural context. Paternalistic leadership is an emerging body of research that has been adapted to the Indonesian context. Javanese cultural values provide a foundation for an Indonesian form of Paternalistic Leadership (PLI). In this study, 178 civil servants in the province of Yogyakarta Special Region, where surveyed in order to examine their responses to the dimensions of PLI. Results suggested that effective PLI emphasises a leader's visibility, benevolence and courage. Authority and impartiality need to be expressed in ways that align with traditional Javanese values. Suggestions of the direction for further study are presented.
\end{abstract}

Abstrak: Fakta bahwa penelitian kepemimpinan sudah banyak dikaji, akan tetapi sangat sedikit riset dilakukan dalam konteks kepemimpinan efektif yang berakar pada budaya Indonesia. Kepemimpinan paternalistik merupakan wacana riset yang sedang berkembang saat ini dan diadopsi untuk konteks budaya Indonesia. Nilai budaya Jawa memberikan fondasi yang kuat untuk model kepemimpinan paternalisik (PLI). Dalam studi ini, 178 PNS di lingkungan Pemerintah Provinsi DIY di survey untuk menilai respon mereka terhadap model PLI. Hasil penelitian membuktikan bahwa PLI yang efektif menekankan pada pentingnya pemimpin untuk selalu tampak, berbuat kebajikan serta mempunyai keberanian diri. Kepemimpinan otoriter dan adil perlu juga ditunjukkan agar selaras dengan nilai-nilai budaya Jawa. Saran-saran serta direksi untuk studi di masa yang akan datang juga dipaparkan dalam artikel ini.

Keywords: authoritarian leadership; benevolent leadership; employee responses; moral-courage; moral impartialness; moral-incorruptness; moral-magnanimity; visible leadership; paternalistic leadership

* Acknowledgement: We would like to thank the IPC Tertiary Institute of New Zealand for the post-doctoral research fellow position, that the main author has worked on, for all its support in making this research is possible. 


\section{Introduction}

Indonesia urgently needs more leaders. This was the conclusion reached in a review of the nation's economic and political health in the late 1990s (Schwartz 2000). More recent reviews suggest that leadership development continues to be a priority, particularly in dealing with on-going concerns over corruption, collusion and nepotism (Budiman and Roan 2005).

But what form of leadership is needed? Rather than adopting leadership practices that have been developed and researched in Western nations, Indonesia needs leadership that is effective with Indonesians. This article discusses efforts made to identify leadership practices that generate positive employee responses amongst people whose working lives are shaped by traditional Javanese values. These efforts are important if Indonesia is to find ways to grow the leadership capacity of the nation.

Leadership is one of the most widely researched topics in the area of organization and management. Since the early 1900s, academics have been developing models to describe what is involved in effective leadership (Stogdill 1974; Westwood and Chan 1995; Dorfman 2004; House et al. 2006; Javidan et al. 2006). Most of these models have originated in North America and form the basis for leadership education in many parts of the world. An implicit assumption in many models and is that what works in one nation or culture will work in any other culture. This assumption, while appealing to researchers, may lead to leadership ineffectiveness (House et al. 1999). Littrell (2002) reported that in more than 3000 leadership studies in Bass and Stogdill's handbook of leadership, cultural practices that should be part of leadership function are ignored.
Many researchers in the field of leadership have recognized that the influence of culture on leadership effectiveness has been neglected, and have started to focus on the factors that influence leadership effectiveness in specific cultural contexts. The relationship between leadership and cultural values is thus becoming a popular topic because researchers are finding that leadership effectiveness is profoundly influenced by these values.

In a recent review of world leadership, the Globe project, Indonesian leadership was described as characterized by a distinctive style which differed from that commonly practiced in Western nations. Managers show a greater preparedness to accept and to employ a charismatic leadership style, balanced by a particularly strong humane-orientation (Irawanto 2009). The Globe findings suggested that in Indonesia followers expect their leaders to give them personal, caring attention and to express this orientation in a highly charismatic manner.

The Globe findings were part of an extensive review of leadership practices. While they gave a valuable overview of Indonesian leadership, they did not examine effective practice in any significant depth. Further work was clearly needed, given the cultural richness of the Indonesian nation. For instance, what sort of charismatic leadership model applies to Indonesian leadership? Does charismatic leadership as applied in North American work well in Indonesian organizations where a more paternalistic form of leadership has traditionally been practiced?(Liddle 1996; Goodfellow 1997).

Efforts to address these questions has primarily been in the form of scholarly work in the fields of history and anthropology (Geertz 1973; (Geertz 1973; Koentrjaraningrat 1985) and business commentaries on 
the form of leadership practiced in the Indonesian organizations (Goodfellow 1997; Liddle and Mujani 2004). Irawanto (2008) argued that a model of Paternalistic Leadership developed in Taiwan (Cheng et al. 2004) had potential for application to the Indonesian context because of similarities between the cultural values of the two nations. In a recent study Irawanto et al. (2010) used the Taiwanese Paternalistic Leadership instrument in a survey of Indonesian civil servants in order to compare the preferred styles of leadership in the two countries. That study showed that Indonesian leadership is very similar to the Paternalistic Leadership identified in Taiwan. The Indonesian leadership style was characterized by seven distinct factors: (1) visible leadership, (2) authoritarian leadership, (3) benevolent leadership, (4) courage, (5) impartialness, (6) incorruptness, and (7) magnanimity. Of these factors, visible leadership distinguished Indonesian leadership from the Taiwanese style.

The Irawanto et al. (2010) study focused on identifying the pattern of factors that make up the Indonesian form of Paternalistic Leadership. It did not relate these factors to other variables associated with leadership effectiveness; in particular, it did not examine the degree to which Paternalistic Leadership produced positive employee responses. In Javanese culture, loyalty to a person is more important that loyalty to an institution (Mulders 1994; Antlöv 2005) so it is important to examine whether the style of leadership being practiced in Indonesian organizations that are influenced by Javanese values, really produces employee satisfaction, loyalty and commitment.

This paper aims to advance the earlier work on Paternalistic Leadership in Indonesia (PLI). In particular, it will explore whether
PLI, as identified by Irawanto et al. (2010), produces a positive effect on employee's response to leadership. It will also examine whether there are interactions among the seven elements of PLI, and how these interactions affect employee responses. Before considering those questions, the paper will review the concept of Paternalistic Leadership, and the values that form the cultural foundation for Paternalistic Leadership in Javanese society and, by extension, in Indonesia as a nation.

\section{Leadership in an Asian Context}

Rost (1991) reviewed the development of leadership theory and the emergence of various "schools of thought" that shaped how leadership is researched, understood and taught. While the various schools of thought appear to be distinct from one another, Rost pointed out that they share a common view: that effective leadership is best understood by focusing attention on what the leader does. Rost argued that leadership is best understood as an "influence relationship" among leaders and followers, and that the attention of scholars needed to shift from the behavior of one party in the relationship - the leader-to the interaction that takes place between both parties.

This relationship-based view of leadership highlights the need to understand the influence of cultural values. A leader's behavior may be understood and appreciated in one cultural context, producing employee responses of satisfaction and commitment. The same behaviors may be misunderstood and resented by employees with a different set of cultural values (Hofstede 2001; House et al. 2004).

Zhou (2006) argued that for a leadership style to be effective in Asia, it needed 
to be characterized by attention to authority, benevolence, and morality. In other words, leaders in Asia are expected to assert control, build up their authority, and give direction to their employees. Employees in Asia, when they encounter such leadership, are expected to comply respectfully. As a part of their benevolent behavior, leaders are expected to express their personal concern for their individual employees, much as parents express care for their children. This description of the leadership relationship is in harmony with what others (Westwood 1997; Cheng et al. 2004; Hao and Lirong 2005) refer to as paternalistic leadership.

Understanding the paternalistic nature of leadership in an Asian context allows greater insight into how Western models of leadership need to be adapted for the Indonesian culture. For example, research has indicated that "charismatic leadership" is an effective style in both the US and, as discussed earlier, in Indonesia. In the US charisma has an important part in the Transformational Leadership model (Bass 1997). The way charisma effects the leadership relationship is, however, very different depending on the context. In the US it is seen as idealized influence that produces feelings of personal power and capability in employees. In Indonesia, on the other hand, the behavior is designed to generate in employees pride in their leader and, in so doing, reduce feelings of fear and shame. This difference in the dynamics of leadership was noted by Dorfman (2004) who warned of the need for careful implementation of leadership models developed in North America. This difference in the dynamics of leadership and the challenges of implementing Transformational Leadership in an Asian context provoked Cheng et al. (2004) to explore the nature of Asian leadership styles and develop their model of Paternalistic Leadership.
Cheng et al. (2004) describes Paternalistic leadership as "a style that combines strong discipline and authority with fatherly benevolence and moral integrity couched in a personalistic atmosphere" p.91 (2004). PL is comprised of three distinct elements, all of which are closely associated with Chinese values: authoritarianism, benevolence and moral leadership (Cheng et al. 2004). Authoritarian leadership means that leaders stress their unquestionable and absolute authority. They exercise rigorous control over, and demand complete obedience from subordinates (Cheng et al. 2004). Benevolent leadership is the display of personal, holistic, and long-term concern for the well being of subordinates. Moral leadership is characterized by a higher degree of personal integrity, self-development, and selflessness. Thus a moral leader demonstrates behavior that conforms to social norms and virtues in order to set an example for others. In so doing leaders demonstrate that their authority is not only for personal benefit but also for the public good (Westwood 1997).

Cheng's model proposes that Paternalistic leadership generates employee responses that are critical to healthy functioning of organizations. Cheng et al. (2004) suggest that an employee's response to a leader's moral behavior will involve increased respect and identification, as they recognize that the leader is acting as an appropriate role model, worthy of imitation. Authoritarian behavior by the leader will generate increased dependence and compliance. And a leader's benevolent behavior I will result in an employee response of gratitude and repayment.

Although the model of PL developed by Cheng et al. (2004) was based on traditional Chinese values, a review by Irawanto et al. (2011) suggested that very similar values existed within the Javanese culture, the 
largest and most influential culture affecting Indonesian society as a whole. They argued that aspects of Javanese culture corresponded to the elements of the PL model, which would likely make PL applicable in the Indonesian context.

Authoritarian leadership is expressed in the Javanese culture as the value of bapakism. Bapakism is associated with autocratic patronage by leaders and the willingness of followers to comply, both of which feature in Javanese society (Antlöv and Cederroth 1994). The Javanese leadership style based on the expression of these values is bapakism, which Rademakers (1998) translates as "father-ism". Bapakism is manifest as a strong respect for the father, and extends beyond family boundaries. Benevolent leadership is rooted in tepo seliro: a set of behaviors that leaders must have if they are to be respected by other people. With tepa seliro behavior, leaders are viewed as practicing their responsibilities toward their followers in a sober and proper manner. Similarly, moral leadership is rooted in the lesson of andhap-ashor ("low profile"). Within Javanese society, displaying correct behavior involves acknowledging social hierarchy and humbling oneself politely when dealing with someone from a higher rank.

The psychological predisposition to adopt aspects of Paternalistic leadership is deeply ingrained in Javanese society. For instance, in Javanese society people's behavior strongly reflects nrimo (acceptance), which is rooted in both cultural and religious practices. This aspect of dependence and compliance is not just symbolic. It also has a deep emotional foundation which can be seen both in the workplace and outside of work activities. Javanese culture combines nrimo with hormat (recognition). As Hildred Geertz (1961) states, hormat is a Javanese term which means the recognition of superior rank by means of the appropriate forms of etiquette. These values are not directly related to power, authority, or even class strata. Rather, they are connected to appropriate etiquette within patronage relationships. Furthermore, followers are expected to completely respect a leader's values and imitate these values as if they were their own.

\section{Indonesia's Tradition of Paternalism}

Paternalistic leadership is well documented in indigenous Indonesian communities, particularly within the nation's largest ethnicity, the Javanese. Traditionally, Javanese leadership has been closely connected to male domination, based on the values of bapakism. Leadership reflected patronage between bapak (father) and anak (child). Bapakism enabled fathers to exercise high levels of authority blended with moral values to which the children were expected to comply. This family setting was a solid foundation of leadership in Indonesia, as Shiraishi (1997) notes:

"The bapak-anak relationship was the only hierarchical relationship in nationalist's Indonesian, as Dewantara said, that resisted all other hierarchical relationships embedded in Dutch, and other languages."

Mulder (1994) argues that an authoritarian, paternalistic form of leadership fits well with the values of the Javanese. For Javanese, and most other ethnic groups in Indonesia, the "father figure" embodies the highest authority. As Mulder (1994) and Rademakers (1998) state, all important decisions are made by the "father", and all members of the group have to obey the father figure, the bapak. It is clear that the value of bapakism confers a high degree of power and 
authority on leaders. Additionally, the expressions of respect to superiors that determine Javanese behaviour in social relations is referred to as ngajeni (Geertz 1961). Ngajeni is the feeling that the other person is superior and that he or she demands real submission to their authority to be expressed in an appropriate way. Consequently, a Javanese ideal is that the leader (he or she) should be admired and honoured (Koentrjaraningrat 1985).

These values became integrated into Indonesian society beyond the Javanese ethnicity, especially after the independence of Indonesia in 1945. As Cribb (2001) notes, the image of the Javanese cannot be separated from that of the Indonesian state. For example the first president of Indonesia, Soekarno, tried to inspire the whole nation to build a truly unified state. McIntryre (2001) translates Soekarno's vision as being "the state of 'all for all', 'one for all, all for one', and 'a state built on mutual cooperation"'. Being the mouthpiece for the Indonesian people and displaying flamboyant Javanese and nominally Muslim behaviour made Soekarno appear charismatic in the eye of the public (Vickers 2005). When speaking to crowds he often included Javanese terms and provided his own interpretation of their meaning. In the period of second president of Indonesia, Soeharto, Javanese philosophies of life were still taken seriously in the formal life of organizations and in the country's bureaucracy, which shaped the national identity at that time (Sarsito 2006).

As Sarsito (2006) states:

"As the President of Indonesia, Soeharto had treated the country and the state as a big Javanese family. He positioned himself not only as the leader, or the King of the country, but also the father of a big family"
Throughout his rule, the longest presidency of Indonesia to date, Soeharto promoted fundamental Javanese philosophies of life, including the ideology of a peaceful life based on avoiding undesirable behavior. This is summed up in the phrase aja kagetan, aja gumunan, and aja dumeb; which Sarsito (2006) translates as, "do not easily be surprised and amazed at whatever happens on earth and you shall not show off yourself". This principle of life was taken from the priyayi attitude which was to be alus (refined). More recently the leadership of the current president Soesilo Bambang Yudhoyono, has been interpreted as based on Javanese cultural principles (Liddle and Mujani 2004). He is Javanese and is well known for his "charismatic" appearances in public (Hughes-Freeland 2007). Recently, this president has shown a greater commitment to run the state with real democracy and in fact to combat KKN, the form of corruption that has been seen by many-especially the public-as characteristic of Indonesian governance (Suryadinata 2011).

Paternalism in Indonesia is also expressed through the stratification of Javanese society. Three different stratum have been described by Geertz (1956): the highest is priyayi (aristocrat); then santri (characterised by strict to adherence of Islam); and the lowest stratum is abangan (village peasants). In today's world these differences between the strata are less evident in the city (Makarim and Pranowo 2006). However, the essence of stratification is still a part of organisational life nationwide, with managerial decisions to do with provision of higher education, seniority and promotions in influenced by the social ranks of those involved (Goodfellow 1997; Shiraishi 1997). Those in the higher strata are expected to express paternalistic concern for those in lower strata. 
Bapakism values of Javanese are not confined to family and social life; they extend into the organizational setting, where leaders are expected to reflect the role that a father plays in the family setting. Recent empirical investigation by Irawanto et al. (2010) has found that leadership in the Indonesia civil service is characterised by a paternalistic atmosphere in which leaders are expected to exercise leadership in ways that are highly visible to employees and others. Koentrjaraningrat (1985) and Liddle (1996) have commented on the Indonesian preference for leaders to be "out in front". This goes beyond serving as a spokesman, as might be expected in individualistic cultures; rather, by being highly visible to followers, leaders provide motivation, a sense of achievement, and convey feelings of support at times when employees need them.

Efforts to find a leadership style that is effective in the Indonesian context need to be guided by the cultural values outlined above. Modern Indonesian leadership, in summary, is strongly influenced by the values of Javanese culture, including the value of bapakism. Leadership relationships in Indonesia operate within a highly paternalistic climate, and leadership practices that operate counter to these values typically face rejection in Indonesian organisations. The literature that has been reviewed in this paper strongly suggests that highly visible leaders who act with authority and behave in ways that are both benevolent and morally correct will generate feelings of commitment and loyalty in subordinates.

To test these assumptions, we have postulated the following hypotheses regarding Paternalistic Leadership in Indonesia (PLI):

\section{H1:PLI has a positive effect on employee responses} generally.
H2: PLI has a positive effect on employee identification and imitation with visible leadership having the most significant effect.

H3:PLI has positive effect on employee compliance and dependence with visible leadership having the most significance effect.

H4: PLI has positive effect on employee gratitude and repayment with visible leadership having the most significance effect.

H5: Each factor of PLI has a positive effect on employee responses.

\section{Methodology}

In this study, the hypotheses regarding PLI were tested by surveying civil servants in government agencies across Yogyakarta Special Region province. Because Indonesia is a nation with many ethnicities, each with its own cultural values, it was decided to limit the study to the cultural values of the largest ethnicity, Javanese. Kim (2002) observed that civil servant is the major occupation of the Javanese people. Focusing the study on civil servants in the Javanese province of Yogyakarta Special Region allowed the researchers to work with a relatively homogenous sample in terms of cultural values.

Our sample consisted of 220 low- to mid-level staff from more than four government agencies in every district. These agencies represented a variety of important sectors in the public service including education, agriculture, health, and administration and governance. The average size of these agencies was 30 civil servants. We obtained 177 valid surveys out of 220 distributed, achieving a return rate of 80 percent. Seventy two percent of the sample was male and 28 percent female. In terms of education the largest proportion of those surveyed had 
achieved a Bachelors degree (38\%), followed by those with a high school degree (34\%). The majority of those surveyed were employed at the staff level $(80 \%)$ with only 15 percent occupying mid-level managerial positions; this benefited the study which sought to examine the responses of employees to the leadership styles from their immediate supervisors.

The independent variable in the study was Paternalistic Leadership in Indonesia (PLI). The instrument used in this study was the same as that used in previous exploratory studies (Irawanto et al. 2010), and was adopted and translated from the original instrument used in by Cheng et al. (2004) in their Taiwanese-based research. Seven dimensions of PLI emerged from the Irawanto et al. (2010) study of Indonesian leadership, and these dimensions have been used in this study. PLI has seven distinct elements: visible leadership, authoritarian leadership, benevolent leadership and four types of moral leadership (incorruptness, courage, impartialness, and magnanimity). Each dimension was measured using a-six point Likert scale ranging from 1 (strongly disagree) to 6 (strongly agree). The internal reliability coefficient was 0.67 for visible leadership scale, 0.87 for authoritarian leadership, 0.80 for benevolent leadership, and $0.77,0.62,0.83,0.70$ for moral leadership (respectively: courage, impartialness, incorruptness, and magnanimity).

The dependent variables were three types of employee responses (ER). The ER instrument was adopted from the Cheng et al. (2004) study. It consists of three distinct elements: respect and identification; dependence and compliance; and gratitude and repayment. Internal reliability coefficients for the three elements were as follows: respect and identification, 0.73; dependence and compliance, 0.64; and gratitude and repayment, 0.71 .

We used employee demographics as the control variable in this study because we believe it is impact on the way they perceived effective leadership. Those control variables are gender, age, education and position. Gender was coded $(1=$ male, and $2=$ female $)$. Age had six categories $(1=$ less than 30 years old, $2=31-35$ years old, etc.). Educational level had five categories $(1=$ below high school, $2=$ high school, $3=$ diploma, $4=$ bachelor, and $5=$ master $)$. Position had three categories (1-staff, $2=$ low-level manager, and $3=$ mid-level manager).

Several statistical procedures were used to examine the hypotheses. To examine the data integrity an outlier test, normality and homoscedasticity was performed (Tabachnick and Fidell 2007). We employed correlation analysis as an initial step, in order to examine intercorrelations between the PLI and ER constructs used in the study (Table 1). The main analysis used was multiple regression analysis. We employed multiple regression analysis to test the effect of PLI on employee responses, regressing each of these on the seven PL components while controlling for employee demographics. To obtain maximum results, we used hierarchical regression analysis to examine the effect of interaction among seven components of PLI on (1) respect and identification, (2) dependence and compliance, (3) gratitude and repayment.

\section{Results}

Table 1 shows the means, standard deviations, reliabilities and intercorrelations for all of the variables. At the level 0.05 and 0.01 
Gadjah Mada International Journal of Business - May- August, Vol.13,No. 2, 2011

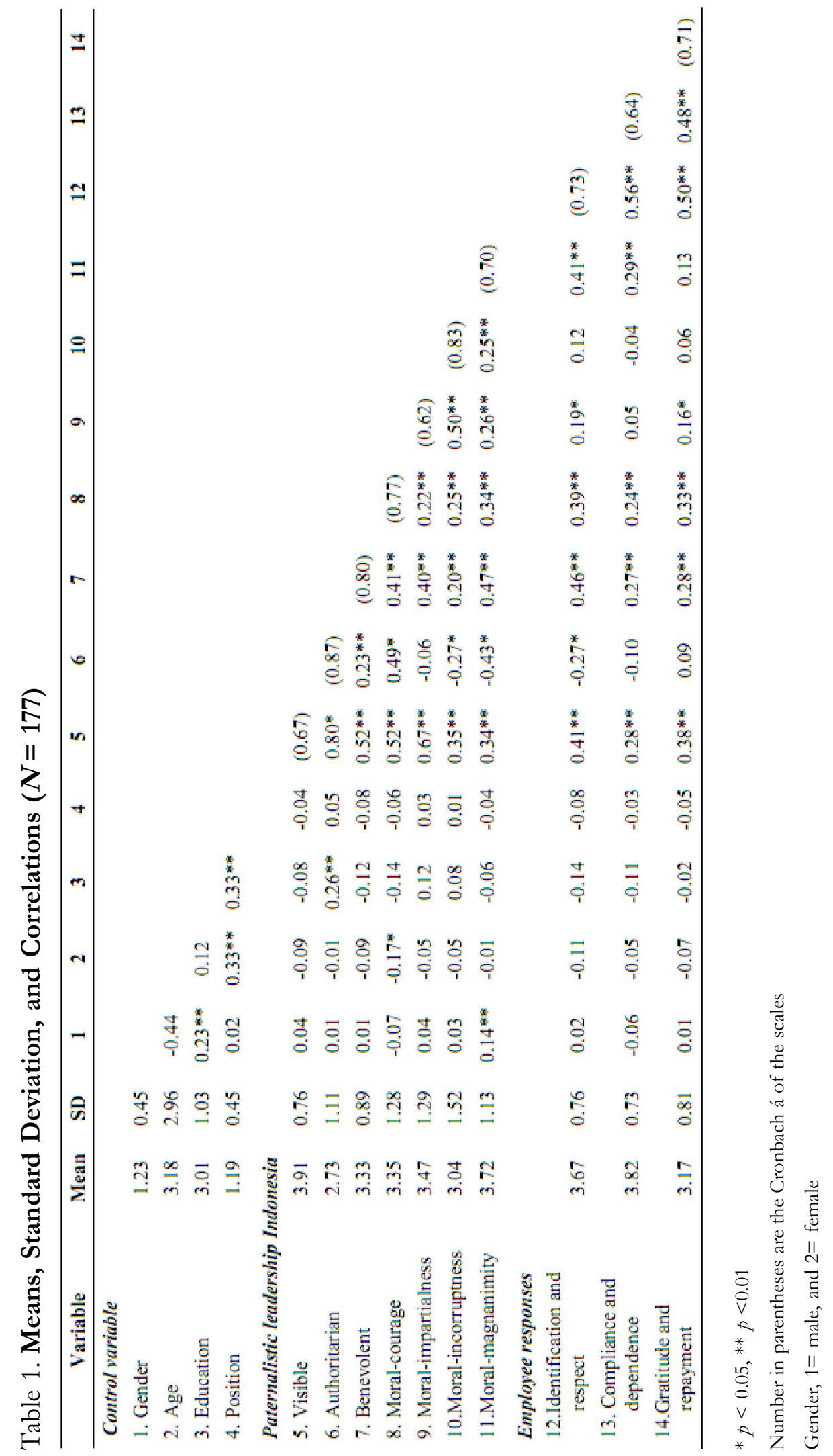


Table 2. Regression Analysis of PLI Scales on Employee Response ( $N=177)$

\begin{tabular}{lccc}
\hline Step 1. Control Variables & $\begin{array}{c}\text { Respect and } \\
\text { Identification }\end{array}$ & $\begin{array}{c}\text { Dependence and } \\
\text { Compliance }\end{array}$ & $\begin{array}{c}\text { Gratitude and } \\
\text { Repayment }\end{array}$ \\
\cline { 2 - 4 } Age & -0.87 & -0.061 & -0.066 \\
Gender & 0.112 & -0.093 & -0.100 \\
Education & -0.163 & -0.050 & 0.083 \\
Position & -0.062 & 0.022 & -0.111 \\
$R^{2}$ & $\mathbf{0 . 0 6 9}$ & $\mathbf{0 . 0 2 6}$ & $\mathbf{0 . 0 2 6}$ \\
Step 2. Paternalistic Leadership & & & \\
Visible & $\mathbf{0 . 3 6 0 ^ { * }}$ & $\mathbf{0 . 4 5 6 *}$ & $\mathbf{0 . 4 0 3}$ \\
Authoritarian & $\mathbf{- 0 . 3 4 2 ^ { * * }}$ & -0.168 & -0.057 \\
Benevolent & $\mathbf{0 . 2 2 1 ^ { * }}$ & 0.161 & 0.211 \\
Moral-courage & $\mathbf{0 . 2 4 5 ^ { * }}$ & 0.089 & 0.162 \\
Moral-impartialness & $\mathbf{0 . 3 1 4 * *}$ & $\mathbf{- 0 . 3 4 4 * *}$ & $\mathbf{- 0 . 3 1 8 ^ { * * }}$ \\
Moral-incorruptness & 0.011 & -0.103 & -0.006 \\
Moral-magnanimity & 0.055 & 0.122 & -0.049 \\
$R^{2}$ & $\mathbf{0 . 4 7 4}$ & $\mathbf{0 . 2 8 3}$ & $\mathbf{0 . 2 4 8}$ \\
Overall $R^{2}$ & & & \\
F-value & 0.543 & 0.309 & 0.274 \\
\hline
\end{tabular}

Significance level $* p<0.05,{ }^{* *} p<0.01$

significance, all dimensions of the Paternalistic leadership instrument had good intercorrelations (ranging from $r=0.87, p$ $\hat{A} 0.05$ as the largest to $r=-0.430, p \hat{A} 0.01$ as the smallest). The exception was between authoritarian leadership and moral-impartialness, where there were no correlations. This correlation patterns suggest a fairly high degree of independence among the seven components of PLI.

The Employee Responses instrument produced similar results, where it was found that the three dimensions of ER had positive intercorrelations, indicating that they are actually measuring the same thing (Brace et al. 2009). These correlations gave us confidence in conducting further analysis to test the hypotheses outlined earlier.
To examine the overall effect of all seven dimensions of PLI on Employee Responses, we regressed each ER dimension on each of the PLI dimensions, along with the control variables. Table 2 presents results of this analysis.

The regression analysis supported the contention that the combined effect of all PLI dimensions is conducive to Employee Responses of respect and identification, dependence and compliance, and gratitude and repayment. This is indicated by the positive $R^{2}$ obtained on the effect of all Paternalistic leadership dimensions on Employee responses. In other words, hypothesis $\mathrm{H}_{1}$ is supported by this analysis. Moreover, it was also found that the Visible Leadership aspect of PLI had a notably positive effect on all dimensions of 
employee response. Hypotheses $\mathrm{H}_{2}, \mathrm{H}_{3}$ and $\mathrm{H}_{4}$ are thus supported as well.

Table 2 shows that the seven leadership dimensions of PLI had different levels of significance in terms of their impact on employee responses with Visible Leadership having the strongest effect in each of the dimensions of ER. Specifically, Visible leadership had the strongest effect on dependence and compliance ( $\hat{\mathrm{a}}=0.456, p<0.05$ ); on respect and identification ( $\hat{\mathrm{a}}=0.360, p<0.05)$; and on gratitude and repayment $(\hat{\mathrm{a}}=0.403, p$ $<0.05)$.

A surprising result was that not all dimensions of PLI had a positive effect on ER, as hypothesized in $\mathrm{H}_{5}$ Authoritarian Leadership had a negative relationship with the employee response of respect and identification. The moral dimension of Impartialness had a negative effect on each of the ER dimensions: specifically, on respect and identification ( $\hat{\mathrm{a}}=-0.314, p<0.01$ ); on dependence and compliance $(\hat{\mathrm{a}}=-0.344, p<0.01)$; and on gratitude and repayment ( $\hat{a}=-0.318, p<0.01)$. Thus, hypothesis $\mathrm{H}_{5}$, that all PLI dimensions would have positive interaction effects with respect to all employee responses was not supported.

\section{Discussion}

For many years, the development of leadership theory appeared to be driven by efforts to find a description of effective leader behavior that would apply universally. With the shift to a relationship-based view of leadership, the need to recognize the role of cultural values in leadership became apparent. Nations like Indonesia, that are seeking to build their leadership capacity need to give attention to models of leadership that work in their specific cultural context.
This study constitutes an early effort to establish what constitutes effective leadership in Indonesia. Rather than attempting to map all the cultural values that influence organizational life in the nation, attention has been focused on the values of the largest ethnicity, Javanese. Earlier work has established that a model of Paternalistic Leadership developed in Taiwan and adapted for the Indonesian context is useful in describing the dimensions of leadership expected by Indonesian civil servants. The purpose of this study was to investigate whether this adapted model (the PLI model) would account for employee responses to leadership in Indonesia's government sector. The present study has important implications regarding the PLI model.

As discussed earlier, the PLI model consists of seven distinct dimensions. Key implications of the current study are that: (1) the combined effect of the seven dimensions - that is, the integrated PLI model as a whole_ - had a positive relationship with employee responses; (2) among the seven dimensions of PLI, Visible Leadership has the most powerful effect on each area of employee response examined; (3) the dimensions of Benevolent Leadership and Courage also had strong relationships with employee responses; and (4) Impartialness had a negative relationship with employee responses.

These results help to draw a clearer picture of the nature and dynamics of leadership relationships in Indonesia. The results highlight that, overall, there are important similarities with leadership relationships in Taiwan. The Taiwanese model of Paternalistic Leadership shares a number of key dimensions with the PLI model, including Benevolent Leadership and Courage. This study also shows that the Taiwanese model cannot be adopted in its entirety for application in In- 
donesia. Javanese cultural values, in particular, give rise to some important differences.

One difference between Indonesian and Taiwanese Paternalistic Leadership is the role of Visible Leadership. In the Taiwanese research, the leader's visibility did not emerge as a distinct dimension. Earlier work in Indonesia (Irawanto et al. 2010) established that it is a distinct dimension of PLI. This study confirmed the importance of Visible Leadership in PLI, by showing that it was the dimension with the greatest impact on employee responses.

A second key difference has to do with the dimension of Impartialness. In the Taiwanese research leaders acting with impartialness were viewed as setting an example of appropriate morals, and employees responded positively to this aspect of leadership. The current research shows that Indonesian employees responded negatively to the same impartialness. Indonesian employees, it seems, expect leaders to relate to them in a highly personal, rather than impartial, way.

To what extent do the differences identified in this empirical research harmonize with qualitative descriptions of Javanese culture?

In regard to Visible Leadership the results of this study are in line with reviews by Koentrjaraningrat (1985) and Liddle (1996) which suggested that leaders in Indonesia should be at the forefront of groups in order to gain responses such as respect, identification, gratitude and compliance. in the public sector the role of leaders goes beyond serving as a "managerial leader" ; it also requires leaders to act in the role of "father" (Goodfellow 1997). It is motivating to employees for their leaders to be role models, and to have a record of achievement that is widely known. Such findings support the idea of Tri Pakarti Utomo (Mulders 1994) which encompass the idea of ideal leaders as exemplary models for their followers (ing ngarso sing tulodo), as individuals who are able to empower followers (ing madyo mangun karso, and have a sense of responsibility (tut wuri handayani).

The negative relationship between Authoritarian Leadership and employee respect and identification was a surprise finding of the study. Culturally in the Javanese setting it is expected that employees will reflect nurut; that is, that they will act with compliance to the commands of a leaders (Shiraishi 1997). In line with commentators such as Keasberry (2001) we expected that respondents from Yogyakarta would still be strongly influenced by traditional Javanese values that encourage leaders to be authoritative. It may be that wording of items in the instrument used suggested that such authority was being expressed in a manner that was kasar (cruel and abrasive). Javanese values encourage people to avoid those who are kasar and respond more positively to leaders who are alus (calm and dignified). An authoritarian leader in this cultural setting would thus be expected to express authority with a light touch or "gentle hints" as recommended by Sajogyo (2002).

While authoritarian leadership was not strongly valued by employees, it is clear from this study that those surveyed placed greater value on the leadership that was visible, benevolent and courageous. The importance for a leader in acting benevolently is expressed by the Javanese concept of tepo seliro, which compels leaders to act with gracious sympathy without concern as to whether the issue at hand is directly connected with the tasks to be performed by the recipient. Similarly, courage is closely associated with andhapashor, a concept which encourages leaders to maintain a proper image in the eyes of others through moral deeds. This includes the report- 
ing of wrongdoing and being brave in order to uphold justice.

The negative effect of Impartialness on all employee responses was, to some degree, unexpected. Traditional Javanese concepts such as andhap-ashor seem to encourage impartialness, yet it was not associated with positive responses from employees. What might account for this? In Javanese culture, the morality of leadership is interpreted in the light of building a proper, personal relationship. In social relations, the Javanese strongly believe in reciprocity between one person and another, and often favors done for others are considered as social investments (Geertz 1961; Hawkins 1996). So, employees expect leaders to act toward them in highly personal ways.

Taken at a surface level, this expectation may seem to give rise to processes of collusion and corruption in decisions about people. However, a personal relationship between leaders and employees does not necessarily translate into a lack of impartialness. A recent commentary by Sultan Hamengkubuwono X in Yogyakarta encouraged civil servants must avoid the "KKN virus" and to act transparently in every aspect of their work, based on the equity norm (Suryanto 2011). This highlights the need for leadership development efforts in Indonesia to help aspiring leaders learn how to reconcile the need for personal relationships and impartial decision making.

\section{Conclusion}

Even though modernization has influenced the way Javanese individuals perceive their leaders' behavior, it seems that, at least amongst participants in this study, their expectations regarding effective leadership are still strongly influenced by traditional Javanese values. As discussed earlier in this paper, leadership needs to be viewed as a relationship-based process, rather than a set of behaviors that are universally effective. For that reason, it is important for those involved in leadership development in Indonesia to build a clear understanding of what constitutes effective practice in the Indonesian cultural context.

Recent research, of which this current study is a part, is enabling a picture of effective leadership practice in an Indonesian cultural context to emerge. Effective leadership in Indonesia takes place in the context of a paternalistic relationship. The model of $\mathrm{Pa}$ ternalistic Leadership in Indonesia is similar to the model developed in Taiwanese research in that it is authoritative, benevolent and involves establishing an example in terms of morality. The Indonesian model appears to be unique in that (1) the visibility of leaders is particularly important, (2) authority needs to be expressed in a dignified manner consistent with alus, and (3) followers' perception of the moral standing of the leader is strongly influenced by the quality of their personal relationship.

While this picture is becoming clearer, it is, at this point in time, based on research that has been limited to the government sector and to the Yogyakarta province in particular. While this has enabled researchers to focus attention on the influence of Javanese cultural values, it means that further research is needed to create a more detailed and extensive picture of effective leadership in Indonesia.

Further research will need to examine whether the PLI model is stable when extended to government agencies in other provinces of Indonesia, and when used to exam- 
ine leadership practices and employee responses in organizations in the private sector. Various sectors of Indonesian society are influenced by a wide range of cultural values, and it is also likely that forces of modernization and globalization affect perceptions in different ways in different sectors.

Further research is also needed to develop a better understanding of how Visible Leadership affects the leader-follower relationship. Research to date has shown that it is a distinct factor in the PLI model, and the current study shows that it is an important determinant of employee responses. More work is needed to explain why it has such a significant impact and how it is most effectively displayed by Indonesian leaders.

Finally, work is also needed to determine how the emerging PLI model can be incorporated into leadership development efforts in Indonesia. As mentioned at the outset of this paper, many commentators have called for greater effort to develop Indonesia's leadership capacity. This can only happen if research such as this is used in directing decisions on the curriculum of leadership development programs.

\section{References}

Antlöv, H., Ed. 2005. The Social Construction of Power and Authority in Java. The Java That Never Was. South East Asian Dynamics.

Antlöv, H., and S. Cederroth. 1994. Leadership on Java: Gentle Hints, Authoritarian Rule. Surrey: Curzon Press.

Brace, N., R. Kemp, and R. Snelgar. 2009. SPSS for Psychologists. New York: Taylor and Francis.

Budiman, A., and A. Roan. 2005. Post-colonial Indonesia: A study of the impact of foreign aid on public sector institutions in West Kalimantan. CMS Conference. Waikato University, New Zealand, Management Department Waikato University.

Cheng, B-S., L.-F. Chou, T-Y. Wu, J-L.L. Farh, and M-P. Huang. 2004. Paternalistic leadership and subordinate responses: Establishing a leadership model in Chinese organizations. Asian Journal Of Social Psychology 7(1): 89-117.

Cribb, R. 2001. Independence for Java? New national projects for an old empire. In G. Lloyd, and S. Smith, Indonesia Today: Challanges of history. Singapore Institute of Southeast Asian Studies.

Dorfman, P. W. 2004. International and cross-cultural leadership research. In B. J. Punnett and O. Shenkar, Handbook for International Management Research. Michigan: University of Michigan Press.

Geertz, C. 1973. The Interpretation of Cultures: Selected Essays. London: Fontana Press.

Geertz, H. 1961. The Javanese Family: A Study of Kinship and Socialization. New York: The Free Press of Glencoe, Inc.

Goodfellow, R. 1997. Indonesian Business Culture. Singapore: Butterworth-Heinemann Asia.

Goodfellow, R. 1997. The new order: President Suharto's government and economy in historical perspective. In R. Goodfellow, Indonesian Business Culture. Singapore: Butterworth-Heinemann Asia.

Hao, Z., and L. Lirong. 2005. A review of paternalistic leadership research. Advances in Psychological Science 13 (2): $227-238$. 
Hawkins, M. 1996. Is rukun dead? Ethnographic interpretations of social change and javanese culture. The Australian Journal of Anthropology 7 (1): 218-234.

Hofstede, G. H. 2001. Culture's Consequences: Comparing Values, Behaviors, Institutions and Organizations Across Culture. CA: Sage Publications.

House, R., P. J. Hanges, S. A. Ruiz-Quintanilla, P. W. Dorfman, S. A. Falkus, and N. M. Ashkanasy. 1999. Cultural influences on leadership and organizations: Project GLOBE. Advances in Global Leadership 1: 171-233.

House, R., P. J. Hanges, M. Javidan, P. W. Dorfman, and V. Gupta. 2004. Culture, Leadership, and Organizations : The GLOBE studies of 62 societies. CA: Sage Publication.

House, R., J., M. Javidan, P. Dorman, and M. Sully de Luque. 2006. A failure of scholarship: Response to George Graen's critiques of Globe. Academy of Management Perspectives 20 (4): 102-114.

Hughes-Freeland, F. 2007. Charisma and celebrity in Indonesian politics. Anthropological Theory 7 (2): 177 200.

Irawanto, D. 2009. An analysis of national culture and leadership practices in Indonesia. Journal of Diversity Management 4 (2): 41-48.

Irawanto, D. W., P. Ramsey, and D. Tweed. 2010. Exploring Paternalistic Leadership and its Application to the Indonesian Public Sector. Palmerston North, New Zealand: Massey University.

Javidan, M., P. Dorfman, M. Sully de Luque, and R. J. House. 2006. In the eye of beholder: Cross cultural lessons in Leadership from Project Globe. Academy of Management Perspectives 20 (1): 67-90.

Koentrjaraningrat. 1985. Javanese Culture. London: Oxford University Press.

Liddle, R. W. 1996. Leadership and Culture in Indonesian Politics. NSW, Australia: Allen \& Unwin Pty Ltd.

Liddle, R. W., and S. Mujani. 2004. Indonesia in 2004: The rise of Susilo Bambang Yudhoyono. Asian Survey 45 (1): 119-126.

Makarim, A. N., and B. Pranowo. 2006. Memperbincangkan Kembali Pemikiran dan Teori Clifford Geert\%: Jakarta, Indonesia: Freedom Institute.

Mulders, N. 1994. The Ideology of Javanese Leadership. In H. Antlöv and S. Cederroth (eds.), Leadership on Java: Gentle Hints, Authoritarian Rule. Surrey, UK: Curzon Press.

Rademakers, M. F. L. 1998. Market organization in Indonesia: Javanese and Chinese family business in the jamu industry. Organization Studies 19 (6): 1005-1027.

Sarsito, T. 2006. Javanese culture as the source of legitimacy for Soeharto's government. Asia Europe Journal 4 (3): 447-461.

Shiraishi, S. S. 1997. Young Heroes: The Indonesian Familiy in Politics. New York: South East Asia Program Publications.

Stogdill, R., M. 1974. Handbook of Leadership: A Survey of Theory and Research. New York: The Free Press.

Suryadinata, L. 2011. Indonesia: The year of a democratic election. Southeast Asian Affairs (Last edited): 131-149.

Suryanto. 2011. Sultan: Pejabat harus jauhi virus KKN. Antara News. Jakarta, Indonesia, Antara

Tabachnick, B. G., and L. S. Fidell. 2007. Using Multivariate Statistics. Boston, MA: Pearson Education.

Vickers, A. 2005. A History of Modern Indonesia. Cambdrige, UK: Cambridge University Press. 
Westwood, R. 1997. Harmony and patriarchy: The cultural basis for 'paternalistic headship' among the overseas Chinese. Organization Studies 18 (3): 445.

Westwood, R. I., and A. Chan. 1995. The transferability of leadership training in the East Asian context. Asia Pacific Business Review 2 (1): 68-92.

Zhou, J. 2006. A Model of paternalistic organizational control and group creativity. In Ya-Ru Chen (ed.), National Culture and Groups (Research on Managing Groups and Teams 9): 75-94. Emerald Group Publishing Limited. 


\section{Appendices}

\section{Appendix 1. Paternalistic Leadership Indonesia (PLI) Sclaes}

\section{Visible Leadership}

1. My supervisor is responsible on job

2. My supervisor is disciplined himself before asking others to be disciplined

3. My supervisor demands that his/her team outperform others

4. My supervisor takes responsibility on job and never shirks his/her duty

5. My supervisor leads rather than follows when we cope with difficulties

6. My supervisor sets an example to me in all aspects

7. My supervisor disciplines me for violations of his/her principles

8. My supervisor asks immediately for reports of changes at work

9. My supervisor always has the last say in the meeting

\section{Authoritarian Leadership}

1. My supervisor looks frightening in front of the employees

2. My supervisor defines an exemplary subordinate as one who acts in accordance with what he/she demands

3. My supervisor grumbles when I fail

4. My supervisor exerts a lot of pressure when we work with him

5. My supervisor would be vexed if I oppose his/her ideas in public

6. My supervisor asks me to completely obey him

7. My supervisor makes all decisions in my department alone

8. My supervisor is very strict with his/her subordinates

\section{Benevolent Leadership}

1. My supervisor cares about not only my work but also my life

2. My supervisor often shows his/her concern for me

3. My supervisor helps me to make my future career plan

4. My supervisor trains and guides me when I'm underperforming

5. My supervisor helps me to solve private problems

6. My supervisor offers necessary help when I am too occupied with work

7. My supervisor understands my preferences enough to accommodate my personal requests 


\section{Moral-incorruptness Leadership}

1. My supervisor does not ask employees to do his needs

2. My supervisor does not use the company's facilities for his own interest

3. My supervisor does not use his power to bribe

\section{Moral-courage Leadership}

1. My supervisor protests about the unfair manner in which other persons are treated

2. My supervisor has the courage to report wrongdoings

3. My supervisor stands up and fights against injustice

\section{Moral-impartialness Leadership}

1. My supervisor does not give any special attention to someone who is close to him

2. My supervisor does not evaluate sub-ordinates based on personal relationships

3. My supervisor does not cover up the mistake of the internal team

\section{Moral-magnanimity Leadership}

1. My supervisor would not mind should his/her opinion be not accepted

2. My supervisor is open-minded and never worries about being offended

3. My supervisor is tolerant of criticismIrawanto ? Paternalistic Leadership and Employee Responses in Javanese Culture 
GadjahMadaInternational Journal of Business - May-August, Vol.13,No.2,2011

Appendix 2. ER (Employee Responses) Scales

\section{Respect and Identification}

1. I very much admire my supervisor's manner and behavior

2. I tell my colleagues or friends about my supervisor's merits

3. My values are becoming more similar to my supervisor's since starting to work here

4. I identify with my supervisor in philosophy and methods for work

5. I always agree with my supervisor's opinions

6. I think my supervisor is a person of foresight

7. I believe my supervisor is always right in his/her decisions

\section{Dependence and Compliance}

1. I completely obey my supervisor's instructions

2. I comply with my supervisor's decisions even if I don't agree with them

3. I exactly abide by my supervisor's philosophy and methods for work

4. When there is a new method to be implemented, I'm willing to follow my supervisor's request

5. I'm ready to conform unconditionally to my supervisor's orders

\section{Gratitude and Repayment}

1. When I get the opportunity, I'll repay my supervisor for the kindness shown

2. I appreciate my supervisor's kindness

3. I would work for supervisor, even if I have to sacrifice my own interests to do so

4. I would sacrifice my own benefits to maintain my supervisor's benefits

5. I take responsibility for what my supervisor has done wrong

6. I would help my supervisor to deal with his/her private business 